\title{
Surface water quality and cropping systems sustainability under a changing climate in the Upper Mississippi River Basin
}

\author{
Y. Panagopoulos, P.W. Gassman, R.W. Arritt, D.E. Herzmann, T.D. Campbell, M.K. Jha, C.L. Kling, \\ R. Srinivasan, M. White, and J.G. Arnold
}

\begin{abstract}
Agricultural nonpoint source pollution is the main source of nitrogen $(\mathrm{N})$ and phosphorus (P) in the intensely row-cropped Upper Mississippi River Basin (UMRB) stream system and is considered the primary cause of the northern Gulf of Mexico hypoxic zone according to the US Environmental Protection Agency. A point of crucial importance in this region is therefore how intensive corn (Zea mays L.)-based cropping systems for food and fuel production can be sustainable and coexist with a healthy water environment, not only under existing climate conditions but also under a changed climate in the future. To address this issue, a UMRB integrated modeling system has been built with a greatly refined 12-digit subbasin structure based on the Soil and Water Assessment Tool (SWAT) water quality model, which is capable of estimating landscape and in-stream water and pollutant yields in response to a wide array of alternative cropping and/or management strategies and climatic conditions. The effects of the following four agricultural management scenarios on crop production and pollutant loads exported from the cropland of the UMRB to streams and rivers were evaluated: (1) expansion of continuous corn across the entire basin, (2) adoption of no-till on all corn and soybean (Glycine max L.) fields in the region, (3) substitution of the traditional continuous corn and corn-soybean rotations with an extended five-year rotation consisting of corn, soybean, and three years of alfalfa (Medicago sativa L.), and (4) implementation of a winter cover crop within the baseline rotations. The effects of each management scenario were evaluated both for current climate and a projected midcentury (2046 to 2065) climate from a General Circulation Model (GCM). All four scenarios behaved similarly under the historical and future climate, generally resulting in reduced erosion and nutrient loadings to surface water bodies compared to the baseline agricultural management Continuous corn was the only scenario which resulted in increased $\mathrm{N}$ pollution while no-till was the most environmentally effective and able to sustain production at almost the same levels. Rye (Secale cereale L.) cover crop within the fallow period was also effective in reducing erosion and both sediment-bound and soluble forms of nutrients. The results indicated that alternative management practices could reduce sediment, $\mathrm{N}$, and $\mathrm{P}$ exports from UMRB cropland by up to $50 \%$ without significantly affecting yields. Results for the climate change scenario showed that the effectiveness of the management scenarios was strongly linked to the reduced water availability predicted under the future climate, which assisted in mitigating pollutant transport, although with a small loss of production.
\end{abstract}

Key words: agricultural management scenarios_ climate change — corn based systems — nonpoint pollution-Soil and Water Assessment Tool-Upper Mississippi River Basin

\begin{abstract}
Overenrichment of nutrients constitutes a major problem in many streams and rivers in the United States. In addition to local effects, transport of these nutrients contributes to environmental problems such as eutrophication in downstream lakes,
\end{abstract}

bays, and estuaries, and is primarily responsible for hypoxia in the Gulf of Mexico (USEPA 2000). The Mississippi River/ Gulf of Mexico Watershed Nutrient Task Force (2008) established a goal to reduce the size of the hypoxic zone in the Gulf of
Mexico to $5,000 \mathrm{~km}^{2}\left(1,900 \mathrm{mi}^{2}\right)$. This will require substantial reductions in nutrient loadings from the Misssissippi/Atchafalaya River Basin and especially from its most upstream and intensively cultivated part, the Upper Mississippi River Basin (UMRB), which forms the western part of the Corn Belt region of the United States. Within this large area, tradeoffs between the interdependent goals of sustainable biofuel production, food production, and water resources can have significant implications for commodity groups, individual producers and other stakeholders in the region.

Within this context, physically based hydrological models can be used to evaluate socioeconomic and environmental impacts of agricultural management scenarios. In order to reliably address what-if scenarios for future agriculture, however, the impacts of future climate change should also be accounted for. The Soil and Water Assessment Tool (SWAT) water quality model (Arnold et al. 1998; Williams et al. 2008) has proven to be an effective tool for evaluating agricultural management simulations for complex landscapes and varying climate regimes, including future climate projections (Gassman et al. 2007, 2013; Douglas-Mankin et al. 2010; Tuppad et al. 2011).

Yiannis Panagopoulos is a postdoctoral research associate at the Center for Agricultural and Rural Development (CARD) at lowa State University in Ames, lowa. Philip W. Gassman is an associate scientist at CARD at lowa State University in Ames, lowa. Raymond W. Arritt is a professor in the Department of Agronomy at lowa State University in Ames, lowa. Daryl E. Herzmann is an assistant scientist in the Department of Agronomy at lowa State University in Ames, lowa. Todd Campbell is a computer programmer at CARD at lowa State University in Ames, lowa. Manoj K. Jha is an assistant professor at North Carolina A\&T State University in Greensboro, North Carolina. Catherine L. Kling is a professor of economics at lowa State University and serves as the division head of CARD's Resource and Environmental Policy Division in Ames, lowa. Raghavan Srinivasan is the director of the Spatial Sciences Laboratory and a professor in the departments of Ecosystem Sciences and Management, and Biological and Agricultural Engineering at Texas A\&M University in College Station, Texas. Michael White is an agricultural engineer at the Grassland Soil and Water Research Laboratory with the USDA Agricultural Research Service (ARS) in Temple, Texas. Jeffrey G. Arnold is an agricultural engineer at the Grassland Soil and Water Research Laboratory with the USDA ARS in Temple, Texas. 
The Soil and Water Assesment Tool has been applied in several previous UMRB based assessments including studies focused on calibration and validation approaches (Srinivasan et al. 2010; Santhi et al. 2012), climate change effects on hydrology and water quality (Jha et al. 2006, 2013; Wu et al. 2012), and evaluation of land use or best management practice (BMP) scenarios (Rabotyagov et al. 2010; Secchi et al. 2011; USDA NRCS 2012; Demissie et al. 2012). However, none of these studies investigated the impact of climate on the efficiency or environmental consequences of alternative management scenarios. Here, we investigate the impacts of both present climate and a projected future climate on the following land use and BMP scenarios for the UMRB: (1) conversion of all cropland to a continuous corn (Zea mays L.; C-C) rotation, (2) adoption of no-till (NT) on all cropland areas, (3) extended rotation of corn-soybean (Glycine max L.; $\mathrm{C}-\mathrm{S}$ ) and C-C with alfalfa (Medicago sativa L.), and (4) the adoption of a winter cover crop (rye [Secale cereal L.]) within rotations of corn and soybean. In addition, a greatly refined SWAT subbasin delineation approach is introduced here; this approach allows for improved linkages to climate data, due to the SWAT structure that requires climate data to be input to a given subbasin from the closest climate station. Refined subbasin structure allows input of downscaled, bias-corrected General Circulation Model (GCM) projections across a dense grid overlaid on the UMRB study region.

\section{Materials and Methods}

Watershed Description. The UMRB is a headwater basin of the Mississippi River and extends from Lake Itasca in Minnesota to just north of Cairo, Illinois, above the confluence with the Ohio River (Srinivasan et al. 2010). It covers approximately 492,000 $\mathrm{km}^{2}$ (190,000 $\left.\mathrm{mi}^{2}\right)$, including large parts of Illinois, Iowa, Minnesota, Missouri, and Wisconsin (figure 1). The area is referred to as Region 07 by the US Geological Survey (USGS) at a 2-digit watershed scale and is further comprised of 131 USGS 8-digit watersheds and 5,729 USGS 12-digit subbasins (figure 2; USGS 2012). The average annual UMRB rainfall within the last 4 decades was $900 \mathrm{~mm}$ (35.4 in), ranging from $600 \mathrm{~mm}$ (23.6 in) to $1,200 \mathrm{~mm}(47.2$ in) across the basin with values generally decreasing from east to west. Cropland

\section{Figure 1}

The 12-digit Upper Mississippi River Basin (UMRB) and the calibration points along Mississippi River and its tributaries.

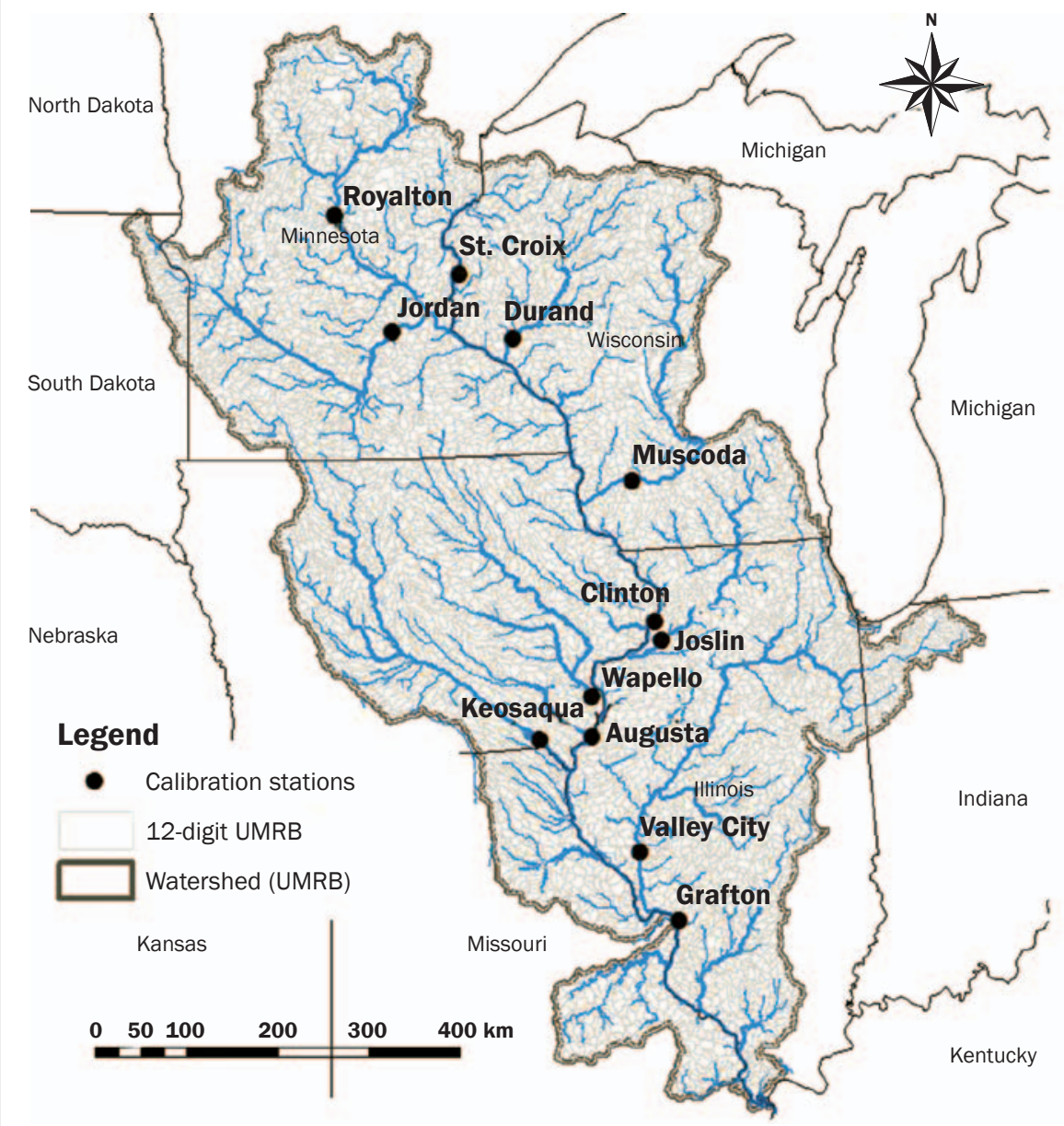

consists mainly of corn-soybean rotations and occupies $50 \%$ of the total UMRB area, with $75 \%$ of the land under gentle slopes. According to USEPA SAB (2007), 43\% of the nitrate $\left(\mathrm{NO}_{3}\right)$ load and $26 \%$ of the total phosphorus (P) load delivered to the Gulf of Mexico came from the UMRB during 2001 to 2005, even though the UMRB covers only $15 \%$ of the total Mississippi River drainage area. The mean annual flow of the Mississippi River at Grafton, Illinois (figure 1), is $3,500 \mathrm{~m}^{3} \mathrm{~s}^{-1}\left(123,600 \mathrm{ft}^{3} \mathrm{~s}^{-1}\right)$, where the river loads for nitrogen $(\mathrm{N})$ and $\mathrm{P}$ have been measured as $500,000 \mathrm{t}(551,000 \mathrm{tn})$ and $30,000 \mathrm{t}(33,060 \mathrm{tn})$ respectively (USGS 2013). More than two-thirds of the total N load occurs as $\mathrm{NO}_{3}-\mathrm{N}$.

Soil and Water Assessment Tool Model Description. SWAT is a river basin model with extensive worldwide use (Gassman et al. 2007). It was developed by the USDA in collaboration with Texas A\&M University (Williams et al. 2008) and is continuously upgraded with improved versions and interfaces. A recent release of SWAT version 2012 (SWAT2012) in combination with the ArcGIS (version 10.1) SWAT (ArcSWAT) interface (SWAT 2013) were used in this study. In SWAT, a watershed is typically delineated into subbasins and subsequently into Hydrologic Response Units (HRUs), which represent homogeneous combinations of land use, soil types, and slope classes in each subbasin (but are not spatially identified within a given subbasin). However, a dominant HRU approach can also be used in which no further delineation of subbasins occurs; i.e., a given subbasin is synonymous with a single HRU (which was the method used in this study). The physical processes associated with water and sediment movement, crop growth, and nutrient cycling are 


\section{Figure 2}

Comparison of US Geological Survey 12-digit watershed versus 8-digit watershed delineation schemes for the Upper Mississippi River Basin.
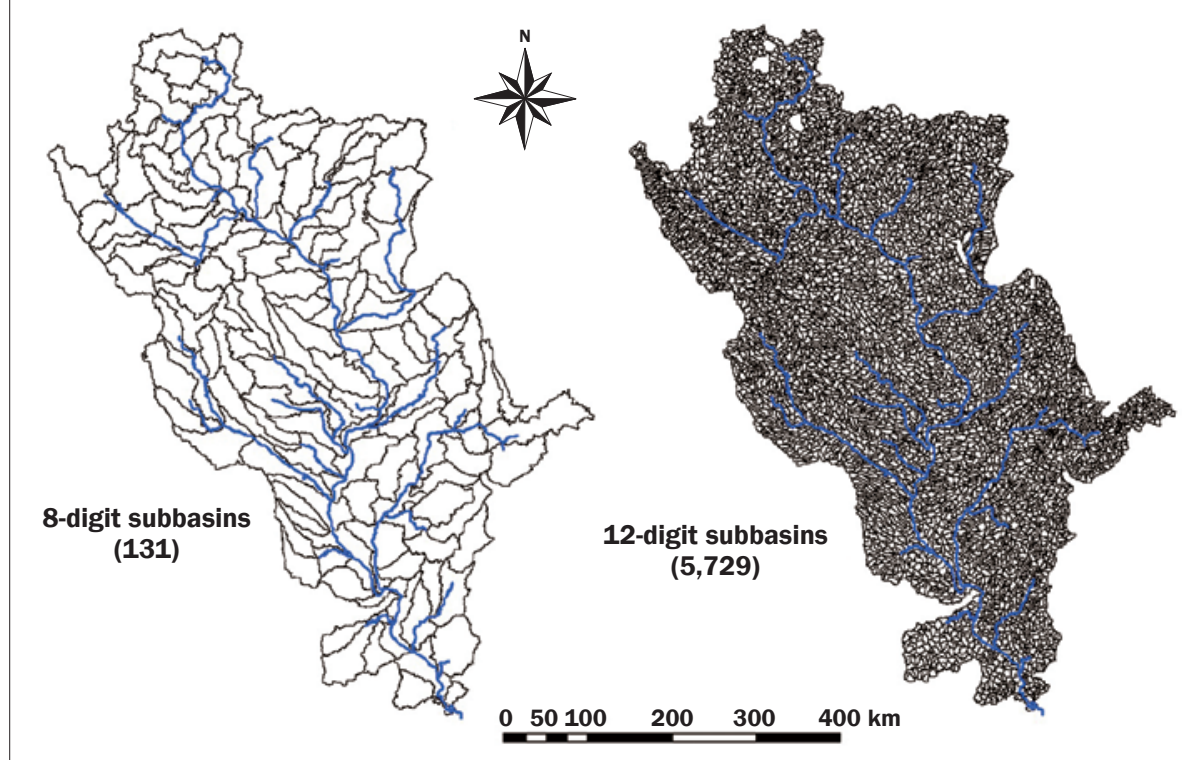

modelled at the HRU scale; runoff and pollutants exported from the different HRUs are aggregated at the subbasin level and routed downstream. Simulation of the hydrology is separated into the land and the routing phase of the hydrological cycle, while sediment yields are estimated with the Modified Universal Soil Loss Equation (MUSLE; Neitsch et al. 2009). SWAT simulates both $\mathrm{N}$ and $\mathrm{P}$ cycling, which are influenced by specified management practices. Both $\mathrm{N}$ and $\mathrm{P}$ are divided in the soil into two parts, each associated with organic and inorganic $\mathrm{N}$ and $\mathrm{P}$ transport and transformations. Agricultural management practices can be simulated with specific dates and by explicitly defining the appropriate management parameters for each HRU. In-field conservation practices such as contour farming, strip-cropping, terraces and residue management are simulated with changes to model parameters that represent cultivation patterns (Arabi et al. 2008).

The Soil and Water Assessment Tool Upper Mississippi River Basin Parameterization. Key data layers that were incorporated for building the UMRB SWAT model included climate, soil, land use, and topographic and management data sources. Topography was represented by a $30 \mathrm{~m}(98.43 \mathrm{ft})$ digital elevation model (USGS 2013) and was used in ArcSWAT to calculate landscape parameters such as slope and slope length. As previously noted, a greatly refined delineation scheme has been incorporated into the current model, which consists of using subbasin boundaries that are coincident with the USGS 12-digit watersheds instead of the coarser 8-digit watersheds, which have been used in previous SWAT UMRB studies (figure 2). The area of a 12-digit watershed is typically 4,000 to 16,000 ha $(10,000$ to $40,000 \mathrm{ac})$, compared with around 200,000 to 400,000 ha $(500,000$ to $1,000,000 \mathrm{ac})$ for an 8 -digit watershed. Historic daily precipitation, and maximum and minimum temperatures were obtained from the National Climatic Data Center (NCDC-NOAA 2012) and were input to the model from a total of more than 1,000 climate stations across the study region. Wind speed, relative humidity, and solar radiation data, required for the estimation of potential evapotranspiration (ET) using the Penman-Monteith method, were generated internally in SWAT using the model's weather generator.

The landuse layer of the UMRB model was created by using the USDA NASS Cropland Data Layer (CDL) datasets (USDA NASS 2012) in combination with the 2001 National Land Cover Data (NLCD 2001). This approach included the overlay of three years of CDL datasets in order to create crop rotations used in the region, similar to the approach reported by Srinivasan et al. (2010) for the UMRB. Two-year rotations of $\mathrm{C}-\mathrm{S}$ rotation dominated within the overall agricultural land portion of the region with a smaller fraction managed with
$\mathrm{C}-\mathrm{C}$ rotation. Soil characteristics were represented by the USDA 1:250,000 State Soil Geographic (STATSGO) soil data (USDA NRCS 2013). The resolution of these data was rather coarse with approximately 600 soil types lying within the UMRB. Thus, we overlaid land use and soils on each of the 5,729 subbasins in ArcSWAT and selected the dominant land use type and soil occupying each subbasin. Therefore, the number of HRUs in this study was equal to the number of subbasins; i.e., one 12-digit subbasin is one HRU. This approach resulted in a slight $(<2 \%)$ increase of the total cropland area compared to the original land use map, with forest being also slightly increased, while other land cover types were reduced accordingly to maintain the sum of all land types equal to the total area of the basin. Minor rotations such as corn-corn-soybean or corn-soybean-wheat (Triticum aestivum) were eliminated in this process, which comprised less than $5 \%$ of the cropland area in any of the 12-digit subbasins.

Estimates of possible locations where subsurface tiles are used to drain soils, a key conduit of $\mathrm{NO}_{3}$ to surface waters, were based on areal county-level estimates compiled by Sugg (2007). Estimates at the county level were first aggregated at the 8-digit level with the use of geographic information system (GIS) applications in order to have the same spatial reference with available fertilizer and tillage data. Tile drains were first assigned to the agricultural subbasins (12-digit watersheds) within each 8-digit watershed with slopes lower than $2 \%$ and with poorly drained soils (hydrologic groups D or C), and subsequently to low-slope, hydrologic group B soils if needed. All tile drains were simulated with the following assumptions: a depth of $1,200 \mathrm{~mm}(3.94 \mathrm{ft})$, the time to drain a soil to field capacity ( 24 hours), and the amount of time required to release water from a drain tile to a stream reach (72 hours), which are the SWAT DDRAIN, TDRAIN, and GDRAIN input parameters, respectively (see Neitsch et al. [2009] for further description of these input parameters).

Spatial representation of various tillage types (conventional, reduced, mulch, and no-till) were incorporated in the modeling system using data reported by Baker (2011), who compiled estimates of the distributions of different tillage types at the 8-digit watershed level using survey data collected by the Conservation Technology Information 
Center. These data were disaggregated to the 12-digit subbasin level, within a given 8 -digit watershed, in a manner that maintained the same distribution of tillage types as reported at the 8-digit watershed level, to the extent possible. Each tillage type was represented by an appropriate number of tillage passes (and corresponding levels of crop residue incorporation), as well as appropriate values of Manning's roughness coefficient for overland flow $\left(\mathrm{OV} \_\mathrm{N}\right)$ and crop cover factor (USLE_C) which is used in the MUSLE erosion estimations (Neitsch et al. 2009).

Regional estimates of the distribution of other conservation practices were not publicly available at the time of this study. To address this deficiency, we used a proxy approach that was based on information provided in the Conservation Effects Assessment Project (Duriancik et al. 2008) UMRB study (USDA NRCS 2012). They reported that more than $45 \%$ of the cropland in the UMRB had at least one in-field conservation practice (terrace, strip-cropping, or contouring), while highly erodible land was managed to a much greater extent compared to less erodible areas. In our model, the conservation practices were likely to be present in all the HRUs due to their relatively large areas (12-digit subbasins). Therefore, we simulated the effect of in-field conservation practices on erosion control in all of them by reducing the management $(P)$ factor of the MUSLE (Neitsch et al. 2009), which was the major parameter that governed the representation of all such practices in the model (Arabi et al. 2008). Similarly, we reduced the slope length, but did not modify HRUs with slopes less than $2.3 \%$ as in those HRUs estimated erosion was inversely correlated with slope length (Arabi et al. 2008). We specified higher reductions of the management $P$ factor in high-sloping agricultural HRUs and slight reductions in low sloping ones. These adjustments of the $P$ factor had also the purpose of calibrating the model for sediment based on model comparisons with observations available from various USGS monitoring stations (USGS 2013). Adjustment of curve numbers (CNs), which are additionally used to represent such practices (Arabi et al. 2008), was not implemented because the CNs served as one of the key parameters for calibrating the hydrological UMRB model (see next subsection), and the reduced $\mathrm{CN}$ values that resulted from the flow calibration during the final 15-year period coincided with expanded adoption of conservation tillage and other conservation practices in the UMRB region.

Fertilizer (including manure) application rates were calculated based on recent estimates at the 8-digit level obtained from the Nutrient Use Geographic Information System (NuGIS) for the United States (IPNI 2010). However, problems were encountered in applying these data in the current modeling system due to uncertainty in the fertilizer sales data used in NuGIS and other factors. Thus, statewide averages computed from the NuGIS data were used in the present study, resulting in annual average $\mathrm{N}$ and $\mathrm{P}$ rates applied to cropland that ranged between 117 to $156 \mathrm{~kg} \mathrm{ha}^{-1} \mathrm{y}^{-1}$ (103 to 137 $\mathrm{lb} \mathrm{ac} \mathrm{yr}^{-1}$ ) and 25 to $34 \mathrm{~kg} \mathrm{ha}^{-1} \mathrm{y}^{-1}$ (22 to $30 \mathrm{lb} \mathrm{ac}^{-1} \mathrm{yr}^{-1}$ ), respectively, with $\mathrm{N}$ applied only to corn. For hay and pastureland we used the autofertilization routine of SWAT by setting a $70 \mathrm{~kg} \mathrm{~N} \mathrm{ha} \mathrm{y}^{-1} \mathrm{y}^{-1}\left(62 \mathrm{lb} \mathrm{ac}^{-1} \mathrm{yr}^{-1}\right)$ as maximum limit.

Monthly streamflow data obtained from 12 UMRB USGS stations (figure 1) were used for calibrating the model (USGS 2013), with the most downstream station located at Grafton, Illinois. These data were obtained for 1975 to 2010, with the most recent 14-year period used for calibration and the rest for validation. In-stream sediment, $\mathrm{NO}_{3}-\mathrm{N}$, organic $\mathrm{N}$, and organic and mineral $\mathrm{P}$ data were available for most of these stations on a monthly basis for similar or shorter time-periods. Calibration of river sediment and nutrient yields was also conducted for all the locations with available data after incorporating $\mathrm{N}$ and $\mathrm{P}$ loads from thousands of point sources across the region (Maupin and Ivahnenko 2011; Dale Robertson, personal communication).

Model Performance and Evaluation. The hydrologic calibration of the UMRB was conducted with the use of the SWAT Calibration and Uncertainty Procedures (SWAT-CUP) software package (Abbaspour 2011). The SWAT-CUP offers a semiautomatic or combined manual/automatic calibration of SWAT projects, allowing the user to control the range of parameter perturbations in seeking to identify their optimum values. Parameters can range either by a percentage from their initial values or within predefined lower and upper bounds. The Sequential Uncertainty Fitting (SUFI2) algorithm (Abbaspour et al. 2007) was used in this study, which is the most efficient option for large regional applications (Schuol et al. 2008a, 2008b) and is highly recommended for the calibration of SWAT models (Arnold et al. 2012).

The calibration of the UMRB model with SUFI-2 was conducted on a monthly basis using the most recent 14-year period of observed flows (1997 to 2010). To make the process feasible with respect to total time needed for thousands of iterations (SWAT runs), we first created SWAT projects for each of the subbasins upstream of the calibration points (figure 1) excluding Clinton and Grafton, which were downstream of the upstream areas with calibration points. Each of the 10 hydrologically independent subregions corresponded to either the most upstream part of the main stem (Mississippi River) or a major tributary flowing into it (i.e., the Minnesota, Iowa, Skunk, Des Moines, St. Croix, Wisconsin, Chippewa, Illinois, and Rock rivers). Each parameterized subproject was manipulated by the SWAT-CUP interface for autocalibration and uncertainty analysis with SUFI-2. This study used eight parameters (Neitsch et al. 2009): five related to groundwater (ALPHA_BF, GW_DELAY, GWQMN, RCHRG_DP, and GW_REVAP), the curve number (CN2), the soil evaporation compensation coefficient and the available soil water capacity of the first soil layer (SOL_AWC[1]), in order to calibrate 10 individual SWAT projects within 500 iterations (runs). The SOL_AWC(1) and $\mathrm{CN}$ were the only parameters allowed to alter by a percentage from the default value $( \pm 20 \%)$, while all others were modified with absolute values within realistic ranges. All projects were executed simultaneously in a personal computer with 32 thread processors and 128 GB random-access memory. The next step was to keep the calibrated values within all the upstream subbasins and calibrate the same eight parameters of the intermediate, still uncalibrated areas above Clinton and Grafton consecutively. The results of the hydrologic calibration (table 1) were evaluated according to the coefficient of determination $\left(r^{2}\right)$ and the Nash-Sutcliffe (NS) modeling efficiency (Krause et al. 2005), and other indices are not reported here. Figure 3 shows the graphs of simulated versus observed data for the entire simulation period including both the most recent years used for calibration (1997 to 2010) and those used for validating model performance (1975 to 1996). 
The SUFI-2 hydrologic calibration was followed by sediment and nutrient calibration, which was performed by manually adjusting the appropriate parameters. As previously mentioned, the management factor (USLE_P) of the MUSLE equation was the primary driving factor of controlling erosion simulation and sediment delivery to streams. River nutrient yields were calibrated based on several other parameters that govern nutrient soil availability and cycling. Some of them were the $\mathrm{N}$ and $\mathrm{P}$ percolation coefficients (NPERCO and PPERCO), the concentrations of organic forms of $\mathrm{N}$ and $\mathrm{P}$ in soil at the beginning of the simulation (SOL_ORGN and SOL_ORGP), as well as the coefficients governing denitrification (Neitsch et al. 2009). The goodness of fit criteria for all these variables, especially the percent bias and the correlation between observed and simulated loads were acceptable both at Grafton and other river locations across the basin and will be documented in a forthcoming study. It is beyond the scope of the current paper to present and discuss the detailed sediment and nutrient calibration approaches and results. Instead, two representative nutrient graphs of observed vs simulated loads at Grafton are included in figure 3 .

General Circulation Model and Predicted Midcentury Climate. The projected future climate was taken from midcentury (2046 to 2065) results from the medium-resolution version of the Model for Interdisciplinary Research on Climate, version 3.2 (MIROC 3.2; Nozawa et al. 2007) GCM. These simulations were performed for the World Climate Research Programme's (WCRP) Coupled Model Intercomparison Project phase 3 (CMIP3). MIROC 3.2 was chosen because it is among the relatively few climate models that reproduce the observed temporal characteristics of the El Niño-Southern Oscillation (ENSO) phenomenon (van Oldenborgh et al. 2005) and which also had output available for all necessary variables. The ENSO has a substantial influence on the climate of our study region (Wang et al. 1999; Watkins and Griffis 2008), and we expected that the ability to represent interannual variability of precipitation would depend the model's ability to represent the variability of ENSO.

MIROC 3.2 is a coupled system of global numerical models for the atmosphere, ocean, sea ice, and land surface (soil and vegetation).
Table 1

Calibration points and statistical results in the Upper Mississippi River Basin (locations are shown in figure 1).

\begin{tabular}{lllll}
\hline Subbasin & Calibration point & $\begin{array}{l}\text { US Geological } \\
\text { Survey station }\end{array}$ & $\boldsymbol{r}^{\mathbf{2}}$ & $\begin{array}{l}\text { Nash-Sutcliffe } \\
\text { efficiency }\end{array}$ \\
\hline Minnesota & Jordan & 5330000 & 0.79 & 0.69 \\
St. Croix & St. Croix Falls & 5340500 & 0.82 & 0.67 \\
Chippewa & Durand & 5369500 & 0.71 & 0.70 \\
Wisconsin & Muscoda & 5407000 & 0.64 & 0.61 \\
Skunk & Augusta & 5474000 & 0.91 & 0.89 \\
Des Moines & Keosaqua & 5490500 & 0.69 & 0.58 \\
Illinois & Valley City & 5586100 & 0.69 & 0.60 \\
lowa & Wapello & 5465500 & 0.79 & 0.75 \\
Royalton & Royalton & 5267000 & 0.50 & 0.48 \\
Rock & Joslin & 5446500 & 0.70 & 0.59 \\
Clinton & Clinton & 5420500 & 0.65 & 0.53 \\
Grafton & Grafton & 5587450 & 0.73 & 0.70 \\
\hline
\end{tabular}

\section{Figure 3}

Simulated versus observed flow time-series at (a) Clinton, lowa, and (b) Grafton, Illinois; and (c) nitrate-nitrogen ( $\mathrm{NO}_{3}$ ), and (d) phosphorus (P) loads at Grafton along the Mississippi River for both the calibration and validation periods.

(a)

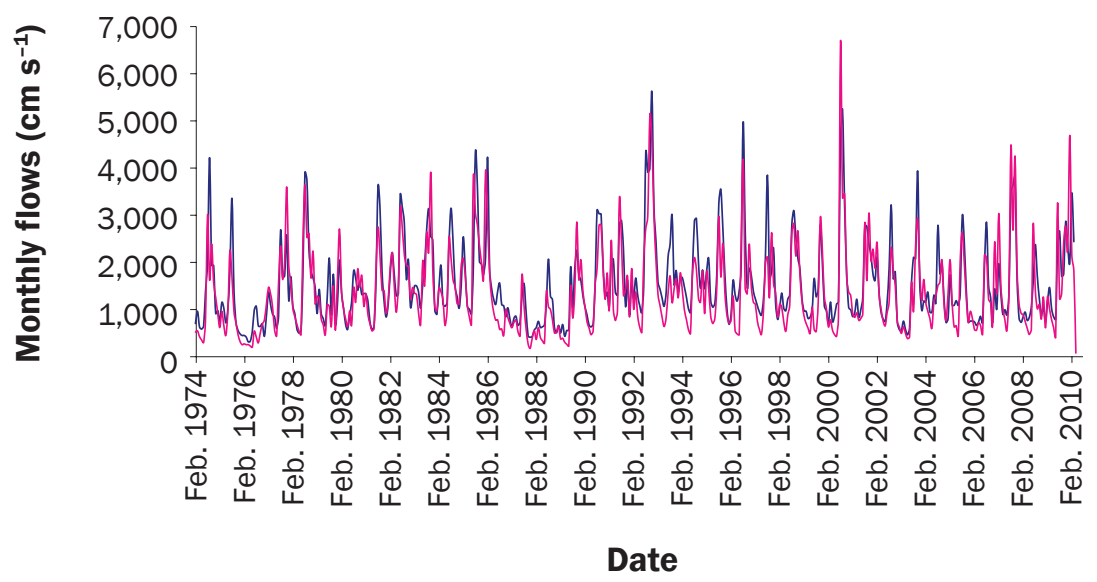

(b)

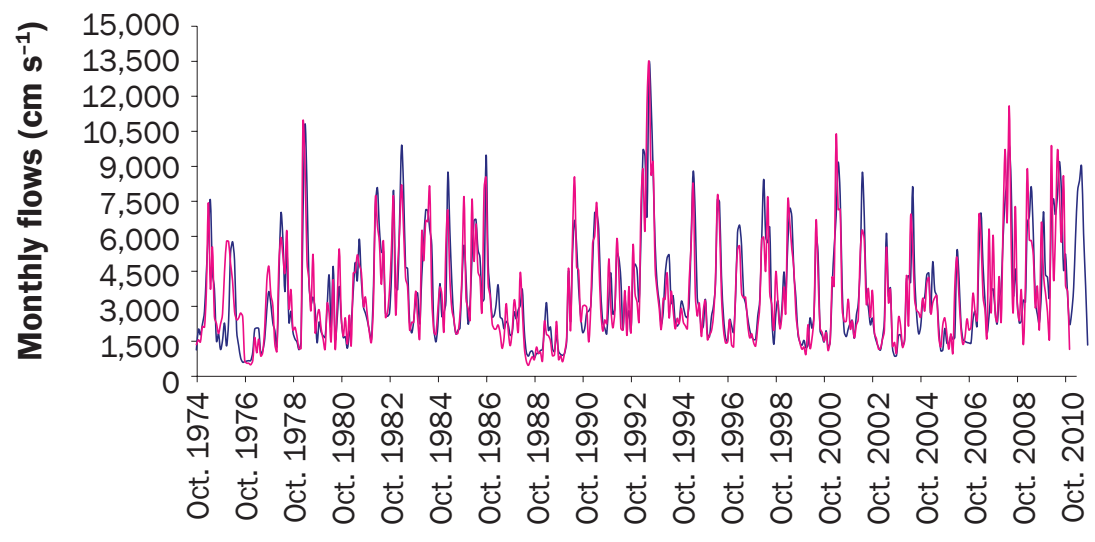

Date 


\section{Figure 3 continued}

(c)

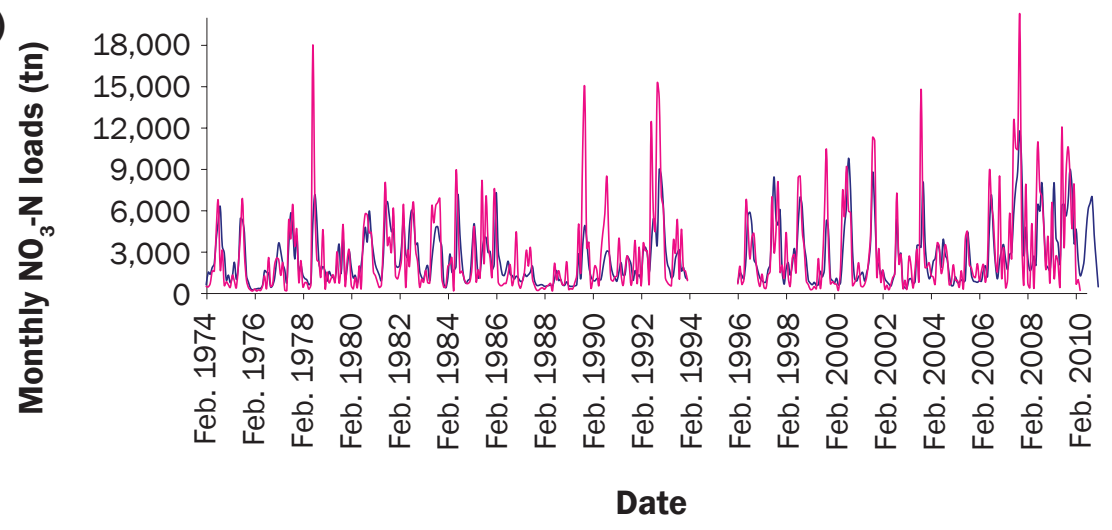

(d)

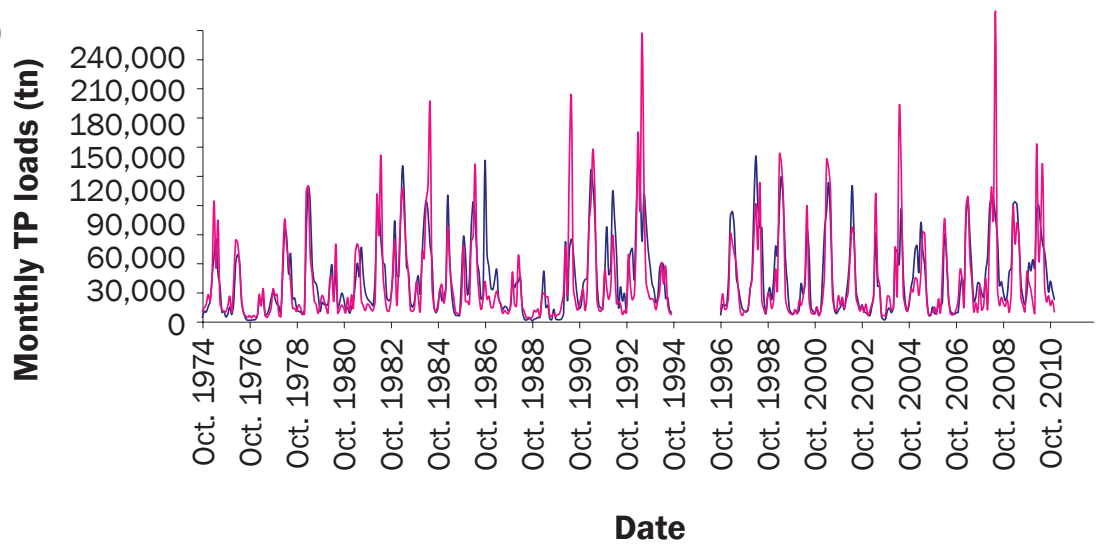

The atmospheric model solves its equations using spectral methods in the horizontal with a triangular truncation of 42 wavenumbers, which approximately corresponds to a horizontal grid of $2.8^{\circ}$ latitude-longitude or around $230 \mathrm{~km}(143 \mathrm{mi})$ over the UMRB. The current climate for MIROC 3.2 is taken as the years 1981 to 1999 from its first ensemble member for the CMIP3 (LLNL 2013) "Climate of the $20^{\text {th }}$ Century" simulations. These simulations include observed forcings from greenhouse gases, natural and anthropogenic aerosols, solar variability, ozone, and land use changes for the period of 1900 to 2000 . The future climate is taken as the years 2046 to 2065 from the corresponding ensemble member for the A1B future climate scenario. In the A1B scenario, emissions of the major greenhouse gases (carbon dioxide $\left[\mathrm{CO}_{2}\right]$, methane $\left[\mathrm{CH}_{4}\right]$, and nitrous oxide $\left.\left[\mathrm{N}_{2} \mathrm{O}\right]\right)$ are assumed to increase through the middle of the 21st century and stabilize or decline thereafter, with $\mathrm{CO}_{2}$ concentrations stabilizing at $720 \mathrm{ppm}$ volume (ppmv). Solar radiation and volcanic aerosols are held at their 2000 values throughout the 21 st cen- tury. An overview of the CMIP3 experiment design is given by Meehl et al. (2007).

For temperature and precipitation, we used monthly downscaled results of the medium-resolution MIROC 3.2 available from the "Downscaled CMIP3 and CMIP5 Climate and Hydrology Projections" archive (Downscaled CMIP3 and CMIP5 Climate and Hydrology Projections 2014). The downscaling method used was bias corrected with spatial disaggregation. In this procedure, biases were first removed from the model's own climatology. Then, the departures from climatology for any given monthly time step were interpolated to a one-eighth degree latitude-longitude grid and superimposed on the observed climatology. The daily observed weather time-series were adjusted with percentage changes in precipitation and absolute changes in maximum and minimum temperatures. Downscaled values for the remaining variables needed by SWAT (monthly solar radiation, dew point, and wind speed) were not directly available. For these we applied the widely used delta method (sometimes called the change factor approach) in which changes between the model's future and current climates were superimposed on historical observed time series (Diaz-Nieto and Wilby 2005), similar to the approach used by Jha et al. (2013). We computed change factors using MIROC 3.2 fields downloaded from the CMIP3 archive and obtained future climate values for use in SWAT by superimposing the resulting changes on the monthly weather generator statistics used in SWAT. The well-calibrated UMRB-SWAT model was then executed with new climatic information to perform the climate change impact assessment. We executed the model for 20 years for both the baseline (1981 to 2000) and the future climate (2046 to 2065).

Agricultural Management Scenarios. Four agricultural management scenarios were selected, formulated, and tested with SWAT under the existing and future climate conditions in UMRB in order to compare their effects on pollutant losses from land to surface waters as well as their ability to sustain corn production. The implementation of these scenarios is of high interest in the Corn Belt, and these scenarios are investigated within the context of the Climate and Corn-based Cropping Systems Coordinated Agricultural Project (CSCAP 2013). The land use and cropping management scenarios included expansion of (1) C-C, (2) NT, (3) extended rotation of the typical C-S and C-C rotations with alfalfa (C-S-A-A-A), and (4) planting of rye as a winter cover crop in alternating years between row crop growing seasons in the $\mathrm{C}-\mathrm{S}$ and $\mathrm{C}-\mathrm{C}$ rotations. All scenarios were implemented entirely or to the greatest feasible extent for the UMRB. Table 2 summarizes implementation of these scenarios in SWAT.

\section{Results and Discussion}

Water Balance under the Historical and Future Climate. The calibrated SWATUMRB model was executed with the current (1981 to 2000) and future (2046 to 2065) climate data. On an average annual basis, precipitation was found to decrease to $829 \mathrm{~mm}$ (32.6 in) from the baseline value of $884 \mathrm{~mm}$ (34.8 in; $7.5 \%$ decrease) for the years 1981 to 2000 , while snowfall was found to decrease to $71 \mathrm{~mm}(2.8 \mathrm{in})$ from the baseline value of $100 \mathrm{~mm}$ (4 in; $29 \%$ decrease). The mean annual temperature averaged across the whole UMRB was $8.2^{\circ} \mathrm{C}\left(47^{\circ} \mathrm{F}\right)$ for the current climate but increased to $12.2^{\circ} \mathrm{C}\left(54^{\circ} \mathrm{F}\right)$ 


\section{Table 2}

Management scenarios implemented in the Soil and Water Assessment Tool (SWAT) simulation of the agricultural land of the Upper Mississippi River Basin (UMRB).

\begin{tabular}{|c|c|c|c|}
\hline Scenario & Where implemented & How implemented in SWAT & Main purpose \\
\hline Continuous corn $(\mathrm{C}-\mathrm{C})$ & $\begin{array}{l}\text { To all corn-soybean } \\
\text { (C-S) rotations of the } \\
\text { baseline in UMRB. }\end{array}$ & $\begin{array}{l}\text { Changing soybean with corn and } \\
\text { increasing } N \text { fertilization by } \\
50 \mathrm{~kg} \mathrm{ha}^{-1} \mathrm{y}^{-1} \text {. }\end{array}$ & $\begin{array}{l}\text { Increase corn production in the } \\
\text { long term. }\end{array}$ \\
\hline No-tillage (NT) & $\begin{array}{l}\text { To all C-S and continuous } \\
\text { corn rotations with } \\
\text { conventional, reduced, or } \\
\text { mulch tillage. }\end{array}$ & $\begin{array}{l}\text { Apply tillage passes with lower depth } \\
(25 \mathrm{~mm}) \text { and low mixing efficiency }(0.05) \\
\text { and reduce the crop factor (USLE_C) in the } \\
\text { crop database. Reduce } \mathrm{CN} \text { values and } \\
\text { increase OV_N. }\end{array}$ & $\begin{array}{l}\text { Reduce erosion, N, and P losses } \\
\text { from fields to waters. }\end{array}$ \\
\hline $\begin{array}{l}\text { Extended rotation } \\
\text { (C-S-A-A-A) }\end{array}$ & To all C-S and C-C rotations. & $\begin{array}{l}\text { Apply the typical C-S and C-C rotations } \\
\text { followed by } 3 \text { years of alfalfa cultivation. } \\
\text { Reduce } \mathrm{CN} \text { values (CNOP) in the third year } \\
\text { when planting alfalfa, increasing them again } \\
\text { when the first crop (corn or soybean) is } \\
\text { planted. Fertilization of alfalfa with } 20 \mathrm{~kg} \\
\mathrm{P} \mathrm{ha}{ }^{-1} \mathrm{y}^{-1} \text { and } 30 \% \mathrm{~N} \text { fertilization } \\
\text { reduction in corn. }\end{array}$ & $\begin{array}{l}\text { Reduce erosion, } \mathrm{N} \text {, and } \mathrm{P} \text { losses } \\
\text { from fields to waters. }\end{array}$ \\
\hline
\end{tabular}

Notes: $\mathrm{N}=$ nitrogen. $\mathrm{P}=$ phosphorus. $\mathrm{CN}=$ curve number for surface runoff simulation. $\mathrm{CNOP}=$ updated curve number due to a specific practice. OV_N = Manning's roughness coefficient for overland flow (Neitsch et al. 2009).

for the future climate. Together with the 1.1 $\mathrm{MJ} \mathrm{m}^{-2} \mathrm{y}^{-1}$ solar radiation increase in the study area, one would expect a considerable increase in mean annual ET, but this was not produced in the SWAT results. We inferred that the increase in potential ET resulting from increased temperature and radiation roughly balanced the decrease of water availability on the ground due to reduced precipitation. SWAT simulated similar annual ET rates: a mean annual ET of 614 $\mathrm{mm} \mathrm{y}^{-1}$ under the baseline climate and 603 $\mathrm{mm} \mathrm{y}^{-1}$ for the future climate (approx. 24 in $\mathrm{yr}^{-1}$ ). Spatial analysis across the basin (not presented here) showed that precipitation alterations in the future climate were maximum (up to $150 \mathrm{~mm}$ [6 in] reduction) in the most southern part of the basin (western Illinois and Missouri area), while reductions in the central part (south and central Iowa and northern Illinois) were between 50 to $100 \mathrm{~mm} \mathrm{y}^{-1}$ (2 to 4 in $\mathrm{yr}^{-1}$ ), and in the northern and northwestern part (Minnesota and Wisconsin) the GCM projected a small variation of $\pm 25 \mathrm{~mm}$ ( $\pm 1 \mathrm{in}$ ) of precipitation on an annual basis. On the contrary, temperature increase was consistent throughout the UMRB area. The predicted streamflow at Grafton, Illinois (figure 1), was 3,250 $\mathrm{m}^{3}$ $\mathrm{s}^{-1}\left(115,000 \mathrm{ft}^{3} \mathrm{sec}^{-1}\right)$ during the present climate (1981 to 2000) and declined to 2,750 $\mathrm{m}^{3} \mathrm{~s}^{-1}\left(97,000 \mathrm{ft}^{3} \mathrm{sec}^{-1}\right)$ during the future climate (2046 to 2065). Annual runoff from the whole basin was reduced to $204 \mathrm{~mm} \mathrm{y}^{-1}$ (8

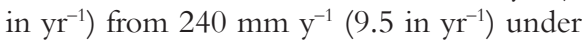
the historical climate, with the surface runoff component being reduced by $20 \mathrm{~mm} \mathrm{y}^{-1}(0.8$ in $\mathrm{yr}^{-1}$ ) or $27 \%$ from the baseline climate (54 $\mathrm{mm}$ instead of $74 \mathrm{~mm}$ [approximately 2 in instead of 3 in]). Subsurface flow, which is the major conduit of $\mathrm{NO}_{3}-\mathrm{N}$, was reduced by $16 \mathrm{~mm} \mathrm{y}^{-1}\left(0.6\right.$ in $\left.\mathrm{yr}^{-1}\right)$ from the baseline value of $166 \mathrm{~mm} \mathrm{y}^{-1}$ (6.6 in $\left.\mathrm{yr}^{-1}\right)$. Thus, the level of decrease was greater for surface runoff than for subsurface flow (baseflow and tile flow). This was considered important for the mitigation of sediment and organic nutrient pollution in the future period, given the strong linkage of surface runoff with erosion and organic materials in SWAT. On the other hand, precipitation reductions mostly occurred in the more intensely cultivated areas of UMRB, which could increase water stress for crop production.

Figure 4 summarizes the seasonal (monthly) variations of three key water balance components simulated under the existing and predicted climate with SWAT.
The GCM predicted increased precipitation in late fall and winter but a considerable decrease from late spring to early fall, which coincides with the UMRB crop growing season. Evapotranspiration did not consistently follow this pattern, but was increased during the first stages of crop growth (May and June) under the predicted climate, which in combination with reduced precipitation caused an overall runoff reduction until the end of summer. The alterations of the water balance components within the growth period, especially the first stages when fertilizers are applied, imply an assisting role of climate change in reducing pollutant losses from land to waters. On the other hand, reduced water availability may have a negative impact on crops, which may meet more water stress days.

Pollutant Losses from Scenario Implementation. In our calibrated SWATUMRB model, sediment losses from the agricultural land under the current climate were $0.95 \mathrm{t} \mathrm{ha}^{-1} \mathrm{y}^{-1}\left(1.0469 \mathrm{tn} \mathrm{ac}^{-1} \mathrm{yr}^{-1}\right)$ within the 20-year baseline period (1981 to 2000). Similarly, $\mathrm{NO}_{3}-\mathrm{N}$ and total $\mathrm{N}$ (TN) losses in the current modeling study were predicted as 14.6 and $19.2 \mathrm{~kg} \mathrm{ha}^{-1} \mathrm{y}^{-1}(12.85$ and $\left.17 \mathrm{lb} \mathrm{ac}^{-1} \mathrm{yr}^{-1}\right)$, respectively. For TP, our 
mean annual prediction was $1.3 \mathrm{~kg} \mathrm{ha}^{-1} \mathrm{y}^{-1}$ $\left(1.1 \mathrm{lb} \mathrm{ac}^{-1} \mathrm{yr}^{-1}\right)$. It should be noted that upland erosion and nutrient outputs from agricultural fields were not directly measurable variables. Pollutant yields were measured and reported along streams and rivers, while the official USGS data corresponded to a lower total $\mathrm{N}$ and $\mathrm{P}$ load on a per hectare of the upstream area basis at Grafton, Illinois, compared to the upland pollution from agricultural fields analyzed by our results. This was mainly attributed to the unit area contribution of nonagricultural areas to water pollution, which was much lower than that of the agricultural land. The reliability of predictions from the agricultural land was based on the ability of SWAT to capture spatial heterogeneity given the accuracy of our model parameterization and the success of the calibration process. However, even though there is some uncertainty regarding the predicted absolute values, the purpose of the study was to analyze relative comparisons of the productivity and the susceptibility of the agricultural land in pollutant loss under various management and climatic conditions, which is a straightforward application of SWAT.

Figure 5 shows the mean annual sediment and $\mathrm{P}$ yields generated from the UMRB agricultural land for both the current and predicted climate and under the implementation of both the baseline management scenario and the four scenarios listed in table 2. These pollutants were closely linked in the UMRB-SWAT model as both organic, and the greatest mineral $\mathrm{P}$ pool were attached to soil particles and transported with them. The C-C scenario resulted in a slightly reduced sediment from HRUs compared with the baseline. Although corn was erodible to the same extent as soybean according to the attributes of both crops in SWAT (USLE_C factor, CN values), the replacement of soybean with corn produces higher residue amounts, resulting in reduced soil erosion. The expansion of NT was the most promising scenario, which resulted in drastic sediment and $\mathrm{P}$ load reduction from the agricultural land. Sediment reduction approached $70 \%$, and $\mathrm{P}$ reduction was $40 \%$. The smaller $\mathrm{P}$ reduction was attributed to mineral forms linked directly with runoff that were not influenced significantly by NT. The extended rotation (C-S-A-A-A) resulted in about $50 \%$ load reductions for both pollutants mainly due to decreased

\section{Figure 4}

Mean monthly precipitation (Prec), evapotranspiration (ET), and runoff in Upper Mississippi River Basin caused with baseline (1981 to 2000) and future (2046 to 2065) climate. GCM = General Circulation Model.

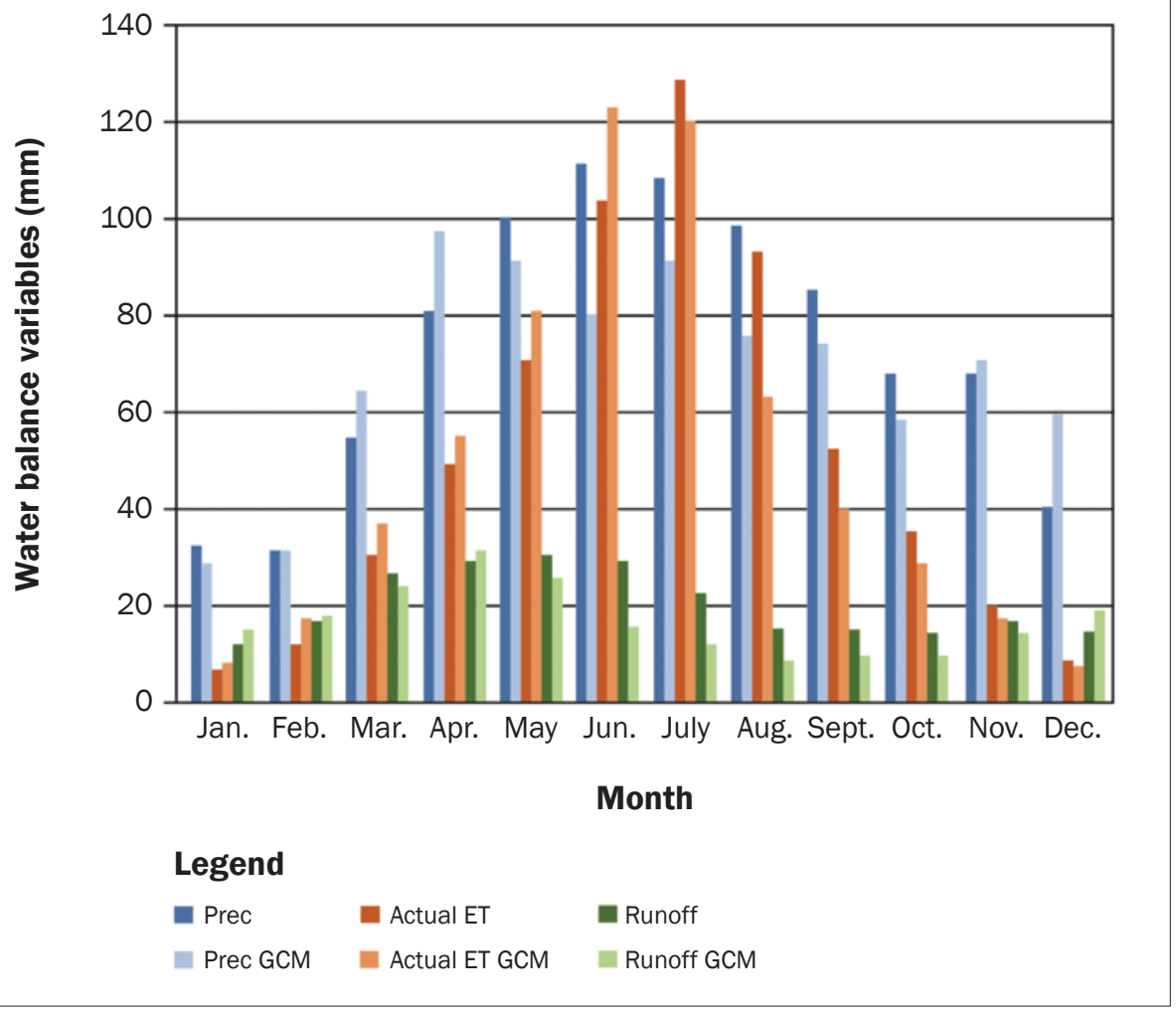

simulated erosion caused by alfalfa. For P, fertilization was slightly reduced compared to corn and soybean which contributed to some extent to the results produced. Finally, the establishment of rye as a winter cover crop within the traditional UMRB rotations $(\mathrm{C}-\mathrm{S}$ or $\mathrm{C}-\mathrm{C})$ resulted in reduced sediment and TP loads of $25 \%$ to $30 \%$, because of increased soil protection. Under the future climate, all scenarios behaved similarly, with both pollutants reduced by a further $20 \%$ to $25 \%$ compared with the baseline management conditions. Reduced precipitation and surface runoff were responsible for this result. All land management scenarios behaved similarly when implemented under the climate change scenario. Pollution was reduced in the future climate, and various management scenarios further decreased pollutant loads.

Figure 6 presents the mean annual $\mathrm{NO}_{3}-\mathrm{N}$ and $\mathrm{TN}$ yields estimated from the UMRB agricultural land with the historical and predicted climate and under the implementation of both the baseline management scenario and the four scenarios listed in table 2. The $\mathrm{NO}_{3}-\mathrm{N}$ losses were highly governed by subsurface flow pathways (tile and baseflow) while the TN losses also included organic $\mathrm{N}$ attached to sediment. The $\mathrm{C}-\mathrm{C}$ scenario resulted in increased $\mathrm{NO}_{3}-\mathrm{N}$ and $\mathrm{TN}$ loads compared to the baseline. Increased $\mathrm{N}$ fertilization of $50 \mathrm{~kg} \mathrm{~N} \mathrm{ha} \mathrm{k}^{-1}\left(44 \mathrm{lb} \mathrm{ac}^{-1}\right.$ $\mathrm{yr}^{-1}$ ) during each year of C-C cultivation, relative to the $\mathrm{N}$ application rates to corn in the $\mathrm{C}-\mathrm{S}$ baseline rotation, was responsible for this increase. The $\mathrm{NO}_{3}-\mathrm{N}$ losses for the C-C scenario increased by $6.7 \mathrm{~kg} \mathrm{ha}^{-1}$ $\mathrm{y}^{-1}\left(5.9 \mathrm{lb} \mathrm{ac}^{-1} \mathrm{yr}^{-1}\right)$ or $45 \%$ from the baseline due to higher $\mathrm{N}$ availability in soil and subsoil. Nitrogen transported with sediment, however, was reduced to some extent due to increased residue levels that resulted in less erosion and sediment transport. This can be inferred from the increase in TN yields (figure 6), which was $6 \mathrm{~kg} \mathrm{ha}^{-1} \mathrm{y}^{-1}\left(5.3 \mathrm{lb} \mathrm{ac}^{-1}\right.$ $\left.\mathrm{yr}^{-1}\right)$, which was less than the corresponding $\mathrm{NO}_{3}-\mathrm{N}$ increase of $6.7 \mathrm{~kg} \mathrm{ha}^{-1} \mathrm{y}^{-1}\left(6 \mathrm{lb} \mathrm{ac}^{-1}\right.$ $\left.\mathrm{yr}^{-1}\right)$. Adoption of NT had little effect on $\mathrm{NO}_{3}-\mathrm{N}$ losses. The model simulated a very slight increase in $\mathrm{NO}_{3}-\mathrm{N}$ rate showing that this soluble $\mathrm{N}$ pool was little affected by the mass of residue on the ground. On the other hand, TN, which was affected by adding organic $\mathrm{N}$ attached to sediment, 


\section{Figure 5}

Average annual sediment (SED) and total phosphorus (TP) losses from the cropland of the Upper Mississippi River Basin with the historical and future climate under the baseline and four agricultural management scenarios: continuous corn (CC), no-till, extended rotation (C-S-A-A-A), and cover crop.

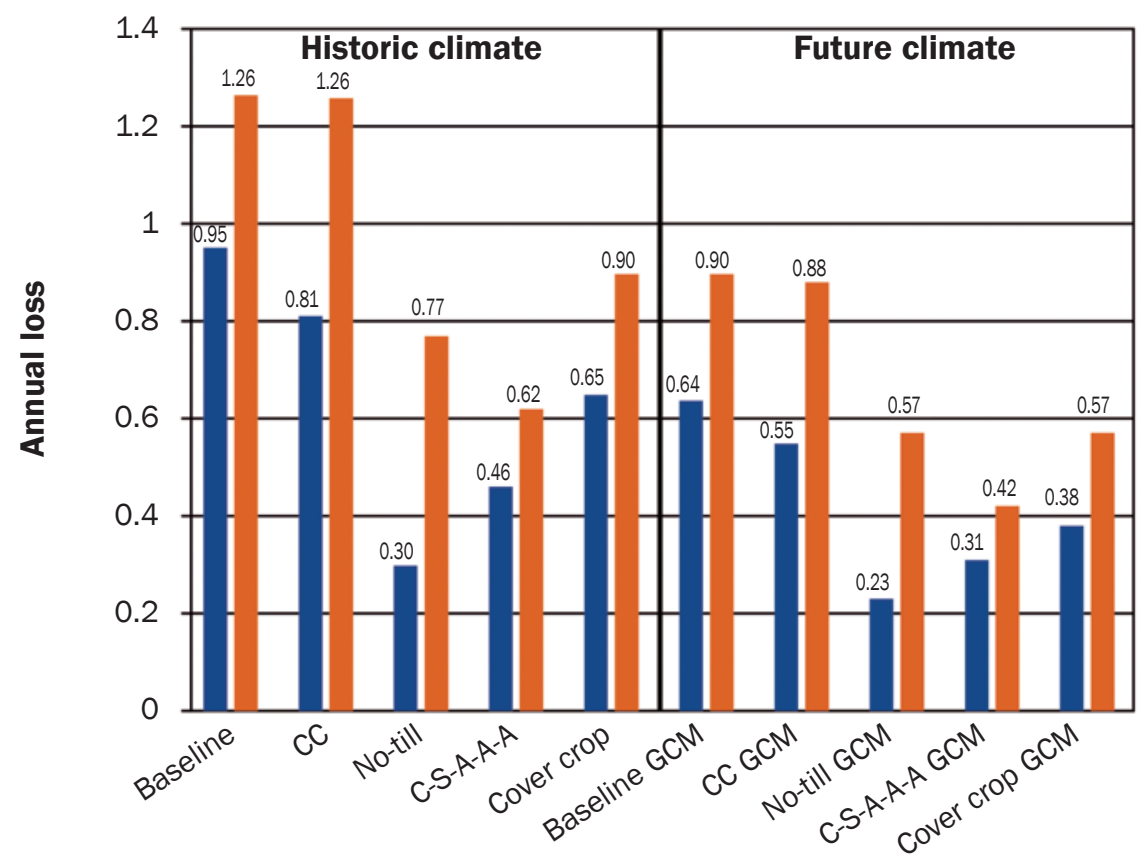

Management

\section{Legend}

घED $\left(\mathrm{t} \mathrm{ha}^{-1}\right) \quad$ TP $\left(\mathrm{kg} \mathrm{ha}^{-1}\right)$

was considerably reduced. The C-S-A-A-A rotation was the most effective management scenario because it resulted in $50 \%$ or more reductions of both $\mathrm{NO}_{3}-\mathrm{N}$ and $\mathrm{TN}$ on a mean annual basis. The reason was not only the reduced erosion but also the absence of $\mathrm{N}$ fertilization in alfalfa. Cover crops had a significant effect on $\mathrm{N}$ pollution mitigation as well. Reductions were on the level of $25 \%$ for both $\mathrm{NO}_{3}-\mathrm{N}$ and $\mathrm{TN}$ due to $\mathrm{N}$ uptake and erosion protection during periods when soils were susceptible to pollutant transport. All four scenarios produced similar results when applied under the future climate. Pollutant levels were consistently lower compared to the respective loads under the historical climate due to the water balance alterations in the future climate. Similarly with $\mathrm{P}$, the future climate scenario resulted in reduced $\mathrm{N}$ from the entire agricultural land of UMRB on a mean annual basis.

Predicted Yields from Scenario Implementation. Figure 7 summarizes the SWAT crop yield results for corn and soy- bean, while their interannual variability is presented in table 3. Mean annual simulated corn and soybean yields in the baseline scenario were 8.9 and $2.9 \mathrm{t} \mathrm{ha}^{-1} \mathrm{y}^{-1}$ (3.56 and $\left.1.16 \mathrm{tn} \mathrm{ac}^{-1} \mathrm{yr}^{-1}\right)$ respectively across the agricultural land of the UMRB. A slightly increased average annual corn yield of 9.3 $\mathrm{t} \mathrm{ha}^{-1} \mathrm{y}^{-1}\left(3.72 \mathrm{tn} \mathrm{ac}^{-1} \mathrm{y}^{-1}\right)$ occurred for the $\mathrm{C}-\mathrm{C}$ scenario, due to the increased $\mathrm{N}$ fertilization. However, under this management scenario corn average yield was calculated from a 20-year yield population, which may have had some statistical impact, because the corn production years were double those simulated in the baseline (10 years of corn). On the other hand, NT applied in all C-S and C-C HRUs of UMRB did not have any impacts on yield. The results can however be considered promising as the practice was able to sustain yields under the new residue management conditions. Finally, reduced crop yields were predicted for both the C-S-AA-A and cover crop scenarios, which were close to $5 \%$ for both corn and soybean. These results showed that SWAT was sensitive to $\mathrm{N}$ fertilization even though corn was preceded by three years of alfalfa, which resulted in increased $\mathrm{N}$ availability in soil. In addition, it is possible that the corn and soybean yields were affected by the climatic conditions in the specific years that both crops were grown in the C-S-A-A-A rotation. This may have caused undesirable effects on the annual simulated growth if these years were among the driest in large parts of the basin. Alfalfa yield was simulated as $7.5 \mathrm{t} \mathrm{ha}^{-1} \mathrm{y}^{-1}(8.265$ tn $\left.\mathrm{ac}^{-1} \mathrm{y}^{-1}\right)$ of alfalfa production and could have again been affected by the climatic conditions during the years that the simulated alfalfa growth occurred. Substantial market changes would have to occur in order for expanded alfalfa production to emerge as a viable crop alternative in the UMRB region.

Finally, corn and soybean yields were also reduced when rye was grown as a winter cover crop. Climate variability effects between years was not present here as the typical C-S, S-C, and C-C rotations of the baseline were applied throughout the 20 -year period. Therefore, the slight reductions $(2 \%$ to $6 \%)$ were attributed to reduced nutrient availability for the subsequent crop due to uptake by rye. Simulated rye yields ranged from $0.2 \mathrm{t} \mathrm{ha}^{-1} \mathrm{y}^{-1}\left(0.2204 \mathrm{tn} \mathrm{ac}^{-1} \mathrm{yr}^{-1}\right)$ in the northern part of the UMRB to $3 \mathrm{tha}^{-1}$ $\mathrm{y}^{-1}\left(3.306 \mathrm{tn} \mathrm{ac}^{-1} \mathrm{yr}^{-1}\right)$ in the most southern, wettest, and warmer parts of the basin.

The predicted corn and soybean yields consistently declined for all four scenarios with reference to the same management conditions of the current climate. The ranking of practices in terms of their influence on yields was the same, with the extended rotation having the highest negative impacts. The reduced precipitation predicted for the future climate period was the main reason for the lower crop yields, due to increased water stress.

The conclusions drawn here were based on an analysis of water quantity and quality variables at the large basin scale. It would be useful to analyze the results by mapping the effectiveness of each scenario in reducing pollution and in sustaining crop yields at the 12-digit subbasin level. However, improved representation of existing conservation practices, nutrient application rates, and other management practice aspects are needed in order to simulate accurate combinations of practices across specific landscapes. Moreover, a next step would be to translate upland pollutant reduction from agricul- 


\section{Figure 6}

Average annual nitrate-nitrogen $\left(\mathrm{NO}_{3}-\mathrm{N}\right)$ and total nitrogen ( $\left.\mathrm{TN}\right)$ losses from the cropland of the Upper Mississippi River Basin with the historical and future climate under the baseline and four agricultural management scenarios: continuous corn (CC), no-till, extended rotation (C-S-A-A-A), and cover crop.

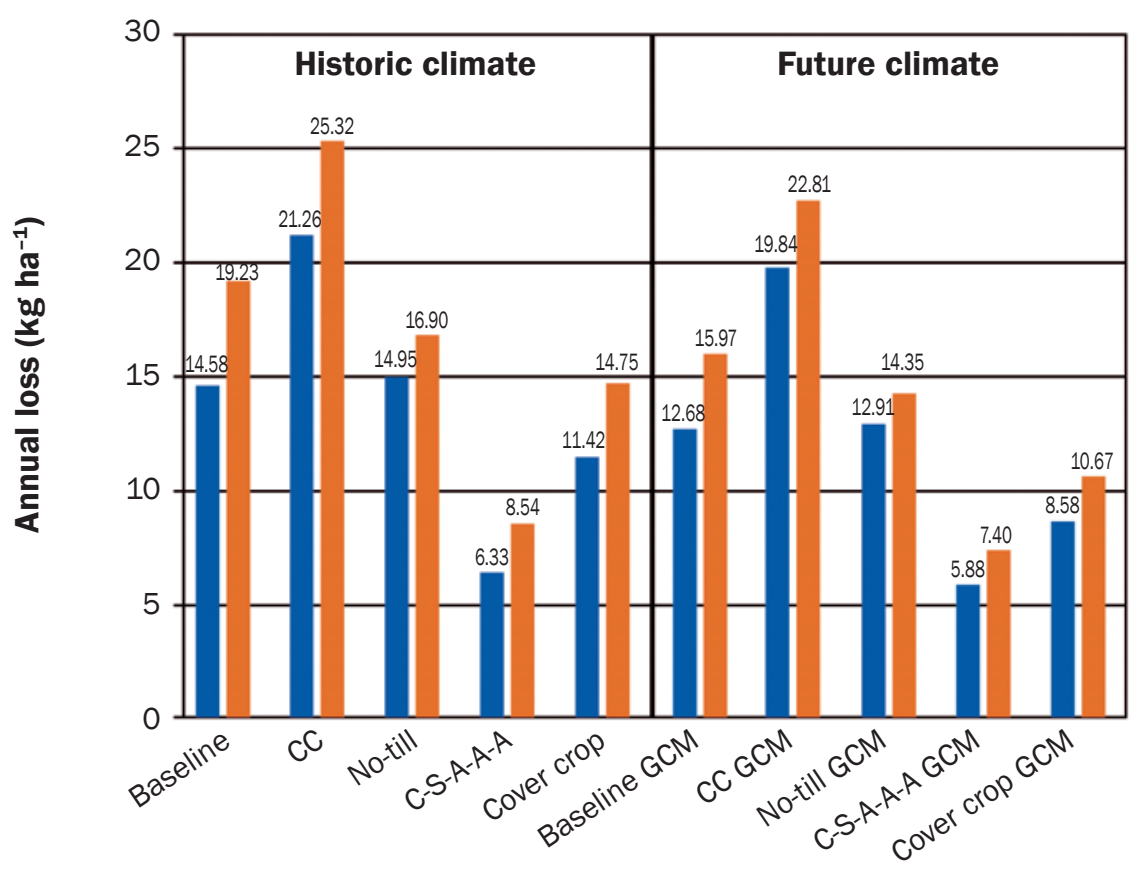

Management

\section{Legend \\ $\mathrm{NO}_{3}-\mathrm{N}\left(\mathrm{kg} \mathrm{ha}^{-1}\right) \quad \square \mathrm{TN}\left(\mathrm{kg} \mathrm{ha}^{-1}\right)$}

ture to precise river pollution levels, which can more closely address the level of pollution in the Gulf of Mexico hypoxic zone. A practice allocation across the landscape of UMRB would also require a clear cost estimation of the practices in different locations. In addition, incorporation of HRUs within the 12-digit subwatersheds is needed to better represent the impacts of different combinations of cropland landscapes and management practices.

This study was based on a future climate projection from a single GCM, the MIROC 3.2 model. A next step in better addressing climate change in the UMRB would be to examine SWAT results using climate projections from an ensemble of different GCMs rather than a single GCM. This could better define the uncertainty of future climate predictions and their impact on SWAT predictions.

\section{Summary and Conclusions}

This study examined the impact of four agricultural management scenarios in the intensely row-cropped UMRB region for both current climate conditions and a climate change projection generated with the MIROC 3.2 model for a future midcentury time period (2046 to 2065). The major effects of the climate projection resulted from reduced precipitation and increased temperature occurring within the crop-growth cycles, especially the first stages of crop development. This reduced soil water availability and runoff potential had a positive effect on pollution mitigation but a slightly negative impact on crop production. All four scenarios behaved similarly under the current and future climate resulting in reduced erosion and nutrient loadings to surface water bodies. Increased $\mathrm{N}$ pollution was predicted only for the $\mathrm{C}-\mathrm{C}$ scenario. No-till was the most environmentally effective scenario and was predicted to sustain crop production levels similar to baseline crop yield estimates. The effective extended fiveyear rotation of the typical crops with alfalfa seemed to be the least economically desirable, given the assumption that alfalfa was less valuable than the other crops. The establishment of rye as a winter cover crop was also effective in reducing erosion and both sediment-bound and soluble forms of nutrients with a small sacrifice in crop yields and would be expected to be even more effective if grown within every winter period, rather than alternating growing periods as simulated in this study. The trend of the simulated effects of the scenarios tested was in agreement with findings from several experiments that were recently reported by the Iowa Department of Agriculture and Land Stewardship (IDALS 2013).

This study highlights the capabilities of SWAT in connecting agricultural management strategies with hydrologic-process simulations at the river basin scale. It also supports its use as a component of an integrated decision support system for the complex Corn Belt agricultural systems. Such tools can provide scientifically based estimates of the effect of a wide array of alternative cropping and management strategies under different climatic conditions, enabling informed choices and affecting environmental and economic sustainability of the region in the coming decades.

\section{Acknowledgements}

This research was partially funded by the National Science Foundation, Award No. DEB1010259, Understanding Land Use Decisions and Watershed Scale Interactions: Water Quality in the Mississippi River Basin and Hypoxic Conditions in the Gulf of Mexico, and by the USDA National Institute of Food and Agriculture, Award No. 20116800230190, Climate Change, Mitigation, and Adaptation in Corn-Based Cropping Systems.

\section{References}

Abbaspour, K.C. 2011. User Manual for SWAT-CUP 4.3.2. SWAT Calibration and Uncertainty Analysis Programs A User Manual. Eawag, Duebendorf, Switzerland: Swiss Federal Institute of Aquatic Science and Technology. http://www.neprashtechnology.ca/Default.aspx.

Abbaspour, K.C., J. Yang, I. Maximov, R. Siber, K. Bogner, J. Mieleitner, J. Zobrist, and R. Srinivasan. 2007. Modelling hydrology and water quality in the pre-alpine/alpine Thur watershed using SWAT. Journal of Hydrology 333:413-430.

Arabi, M., J.R. Frankenberger, B.A. Engel, and J.G. Arnold. 2008. Representation of agricultural conservation practices with SWAT. Hydrological Processes 22(16):3042-3055, doi: 10.1002/hyp.6890.

Arnold, J.G., D.N. Moriasi, P.W. Gassman, K.C. Abbaspour, M.J. White, R. Srinivasan, C. Santhi, R.D. Harmel, A. van Griensven, M.W. Van Liew, N. Kannan, and M.K. Jha. 2012. SWAT: Model use, calibration, and validation. Transactions of the American Society of Agricultural and Biological Engineers 55(4):1491-1508.

Arnold, J.G., R. Srinivasan, R.S. Muttiah, and J.R. Williams. 1998. Large area hydrologic modeling and assessment 


\section{Figure 7}

Average annual corn and soybean yields for the years when the crops are growing in Upper Mississippi River Basin with the historical and future climate under the baseline and four agricultural management scenarios: continuous corn (CC), no-till, extended rotation (C-S-A-A-A), and cover crop. Corn and soybean in the C-S-A-A-A scenarios grow once every five years, thus their average annual production within the entire simulation period is calculated by diving yields by five.

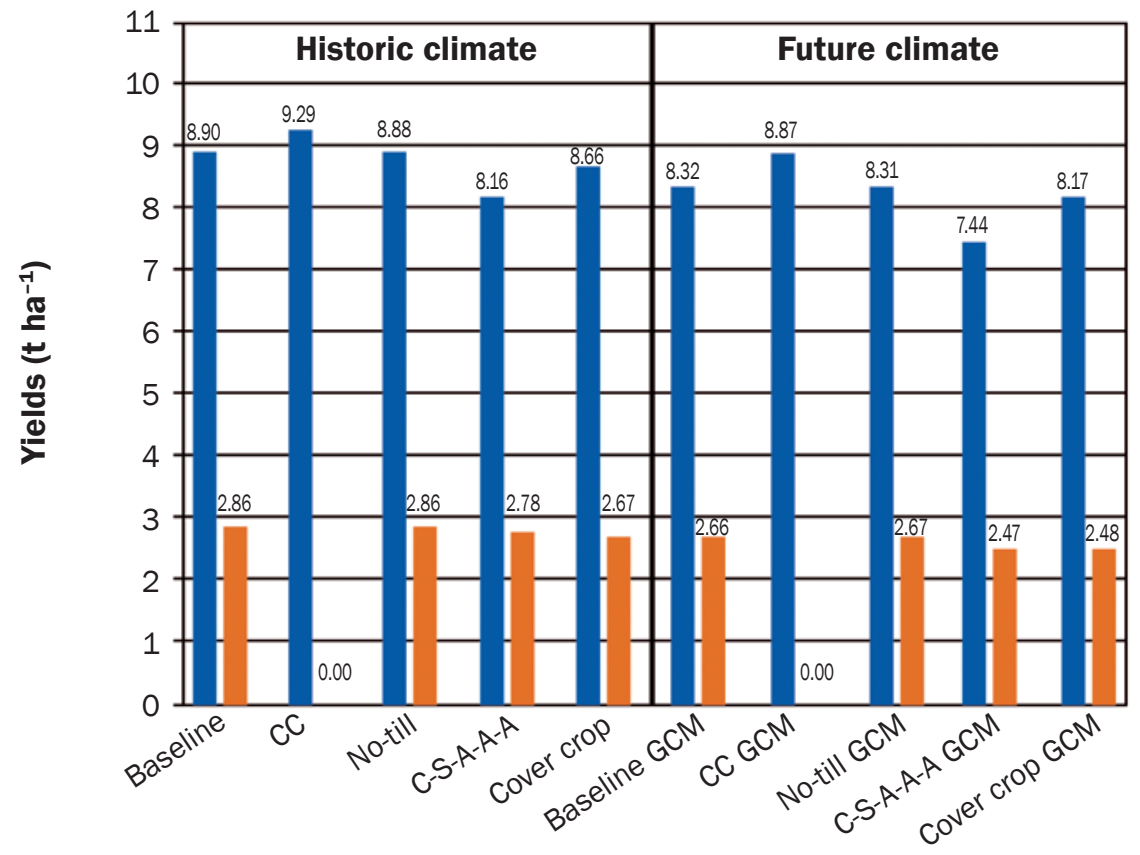

Management

\section{Legend}

Corn yield (t ha-1)

Soybean yield $\left(\mathrm{t} \mathrm{ha}^{-1}\right)$ part I: Model development. Journal of the American Water Resources Association 34(1):73-89, doi: 10.1111/ j.1752-1688.1998.tb05961.x.

Baker, N.T. 2011. Tillage Practices in the Conterminous United States, 1989-2004-Datasets Aggregated by Watershed. Data Series 573. Reston, Virginia: US Geological Survey. http://pubs.usgs.gov/ds/ds573/.

CSCAP (Cropping Systems Coordinated Agricultural Project). 2013. Climate Change, Mitigation, and Adaptation in Corn-based Cropping Systems. http:// www.sustainablecorn.org/.

Demissie, Y., E. Yan, and M. Wu. 2012. Assessing regional hydrology and water quality implications of large-scale biofuel feedstock production in the upper Mississippi River basin. Environmental Science \& Technology 46:9174-9182, doi:10.1021/es300769k.

Diaz-Nieto, J., and R.L. Wilby. 2005. A comparison of statistical downscaling and climate change factor methods: Impacts on low flows in the River Thames, United Kingdom. Climatic Change 69:245-268.

Douglas-Mankin, K.R., R. Srinivasan, and J.G. Arnold. 2010. Soil and Water Assessment Tool (SWAT) model: Current developments and applications. Transactions of the American Society of Agricultural and Biological Engineers 53(5):1423-1431.

Downscaled CMIP3 and CMIP5 Climate and Hydrology Projections. 2014. Downscaled CMIP3 and CMIP5 Climate and Hydrology Projections Archive. http:// gdo-dcp.ucllnl.org/downscaled_cmip_projections/ dcpInterface.html.

Duriancik, L.F., D. Bucks, J.P. Dobrowolski, T. Drewes, S.D. Eckles, L. Jolley, R.L. Kellogg, D. Lund, J.R. Makuch, M.P. O'Neill, C.A. Rewa, M.R. Walbridge, R. Parry, and M.A. Weltz. 2008. The first five years of the Conservation Effects Assessment Project. Journal of Soil and Water Conservation 63(6):185A-197A, doi:10.2489/jswc.63.6.185A

\section{Table 3}

Analysis of Soil and Water Assessment Tool simulated yields in the Upper Mississippi River Basin for the period 1981 to 2000 or 2046 to 2065 (General Circulation Model scenario). CC = continuous corn. GCM = General Circulation Model.

\begin{tabular}{|c|c|c|c|c|c|c|c|c|c|c|}
\hline Yield & Baseline & No-till & $\begin{array}{l}\text { Cover } \\
\text { crop }\end{array}$ & CC & $\begin{array}{l}\text { Extended } \\
\text { rotation }\end{array}$ & $\begin{array}{l}\text { Baseline } \\
\text { GCM }\end{array}$ & $\begin{array}{l}\text { No-till } \\
\text { GCM }\end{array}$ & $\begin{array}{l}\text { Cover } \\
\text { crop } \\
\text { GCM }\end{array}$ & $\begin{array}{l}\text { CC } \\
\text { GCM }\end{array}$ & $\begin{array}{l}\text { Extended } \\
\text { rotation } \\
\text { GCM }\end{array}$ \\
\hline \multicolumn{11}{|l|}{ Corn yields } \\
\hline Minimum (t ha $\left.{ }^{-1}\right)$ & 7.67 & 7.69 & 6.95 & 8.45 & 7.64 & 6.94 & 6.96 & 6.36 & 7.07 & 7.14 \\
\hline Maximum (t ha-1) & 10.58 & 10.56 & 10.39 & 10.07 & 8.59 & 9.54 & 9.54 & 9.28 & 9.88 & 7.70 \\
\hline Average (t ha-1) & 2.86 & 2.86 & 2.67 & - & 2.78 & 2.66 & 2.67 & 2.48 & - & 2.47 \\
\hline Minimum (t ha $\left.{ }^{-1}\right)$ & 2.24 & 2.24 & 2.20 & - & 2.70 & 2.03 & 2.04 & 2.25 & - & 2.28 \\
\hline Maximum(t ha-1) & 3.11 & 3.11 & 3.50 & - & 2.92 & 2.93 & 2.93 & 3.12 & - & 2.63 \\
\hline $\mathrm{SD}\left(\mathrm{t} \mathrm{ha}^{-1}\right)$ & 0.21 & 0.21 & 0.27 & - & 0.09 & 0.19 & 0.19 & 0.21 & - & 0.15 \\
\hline
\end{tabular}


Gassman P.W., M.R. Reyes, C.H. Green, and J.G. Arnold. 2007. The Soil and Water Assessment Tool: Historical development, applications, and future research directions. Transactions of the American Society of Agricultural and Biological Engineers 50(4):1211-1250.

Gassman, P.W., A.M. Sadeghi, and R. Srinivasan. 2013 Overview and insights regarding the JEQ Soil and Water Assessment Tool (SWAT) special issue. Journal of Environmental Quality (submitted).

IDALS (Iowa Department of Agriculture and Land Stewardship). 2013. Iowa Nutrient Reduction Strategy: A science and technology-based framework to assess and reduce nutrients to Iowa waters and the Gulf of Mexico. Iowa Department of Agriculture and Land Stewardship (IDALS), Des Moines, IA; Iowa Department of Natural Resources (IDNR), Des Moines, IA; and Iowa State University College of Agriculture and Life Sciences (ISUCALS), Ames, IA. http://www.nutrientstrategy. iastate.edu/documents.

IPNI (International Plant Nutrition Institute). 2010. A preliminary Nutrient Use Geographic Information System (NuGIS) for the US International Plant Nutrition Institute (IPNI), Norcross, GA. http://www. ipni.net/nugis.

Jha, M., J.G. Arnold, P.W. Gassman, F. Giorgi, and R.R. Gu. 2006. Climate change sensitivity assessment on Upper Mississippi River Basin streamflows using SWAT. Journal of the American Water Resources Association 42(4):997-1016, doi:10.1111/j.1752-1688.2006. tb04510.x.

Jha, M.K., P.W. Gassman, and Y. Panagopoulos. 2013. Regional changes in nitrate loadings in the Upper Mississippi River Basin under predicted mid-century climate. Regional Environmental Change, doi. 10.1007/s10113-013-0539-y.

Krause, P., D.P. Boyle, and F. Bäse. 2005. Comparison of different efficiency criteria for hydrological model assessment. Advances in Geosciences 5:89-97, doi:10.5194/adgeo-5-89-2005.

LLNL (Lawrence Livermore National Laboratory). 2013 About the WCRP CMIP3 multi-model dataset archive at PCMDI. Lawrence Livermore National Laboratory, Livermore, CA. http://www-pcmdi.llnl.gov/ipcc/ about_ipcc.php.

Maupin, M.A., and T. Ivahnenko. 2011. Nutrient loadings to streams of the continental United States from municipal and industrial effluent. Journal of the American Water Resources Association 47(5): 950-964. doi: 10.1111/j.1752-1688.2011.00576.x.

Meehl, G.A., C. Covey, T. Delworth, M. Latif, B. McAvaney, J.F.B. Mitchell, R.J. Stouffer, and K.E. Taylor. 2007. The WCRP CMIP3 multi-model dataset: A new era in climate change research. Bulletin of the American Meteorological Society 88:1383-1394, doi: 10.1175/BAMS-88-9-1383.

Mississippi River Gulf of Mexico Watershed Nutrient Task Force. 2008. Gulf Hypoxia Action Plan 2008 for Reducing, Mitigating, and Controlling Hypoxia in the Northern Gulf of Mexico and Improving Water Quality in the Mississippi River Basin, Washington, DC.

NLCD (National Land Cover Database).2001. National Land Cover Database for the Conterminous United States. http://www.asprs.org/publications/pers/2007journal/ april/highlight.pdf.

NCDC-NOAA (National Climatic Data Center - National Oceanic and Atmospheric). 2012. National climatic data center website: http://www.ncdc.noaa.gov/.

Neitsch, S.L., J.G. Arnold, J.R. Kiniry, and J.R.Williams. 2009. Soil and Water Assessment Tool (SWAT) Theoretical Documentation. Blackland Research Center, Texas. Agricultural Experiment Station, Temple, Texas (BRC Report 02-05). http:// swatmodel.tamu.edu/documentation.

Nozawa, T., T. Nagashima, T. Ogura, T.Yokohata, N. Okada, and H. Shiogama. 2007. Climate change simulations with a coupled ocean-atmosphere GCM called the Model for Interdisciplinary Research on Climate: MIROC. CGER'S Supercomputer Monograph Report No. 12. Center for Global Environmental Research, National Institute for Environmental Studies, Tsukuba, Japan. http:// http://www.cger.nies. go.jp/publications/report/i073/I073.pdf.

Rabotyagov S., T. Campbell, M.K. Jha, P.W. Gassman, J.G. Arnold, L. Kurkalova, S. Secchi, H. Feng, and C.L. Kling. 2010. Least cost control of agricultural nutrient contributions to the Gulf of Mexico Hypoxic Zone. Ecological Applications 20(6):1542-1555, doi: 10.1890/08-0680

Santhi, C., N. Kannan, M. White, M. Di Luzio, J.G. Arnold, X. Wang and J.R. Williams. 2012. An integrated modeling approach for estimating the water quality benefits of conservation practices at river basin scale. Journal of Environmental Quality, doi: 10.2134/ jeq2011.0460.

Schuol, J., K. C. Abbaspour, R. Srinivasan, and H. Yang. 2008a. Estimation of freshwater availability in the West African sub-continent using the SWAT hydrologic model. Journal of Hydrology 352(1-2):30-49, doi: 10.1016/j.jhydrol.2007.12.025.

Schuol, J., K.C. Abbaspour, H. Yang, R. Srinivasan, and A.J.B. Zehnder. 2008b. Modeling blue and green water availability in Africa. Water Resources Research. 44(W07406):1-18, doi: 10.1029/2007WR006609

Secchi S., P.W. Gassman, M.K. Jha, L. Kurkalova, and C.L. Kling. 2011. Potential water quality changes due to corn expansion in the Upper Mississippi River Basin. Ecological Applications 21(4): 1068-1084. doi: 10.1890/09-0619.1.

Srinivasan R., X. Zhang, and J. Arnold. 2010. SWAT ungauged: Hydrological budget and crop yield predictions in the Upper Mississippi River Basin. Transactions of the American Society of Agricultural and Biological Engineers 53(5):1533-1546.

Sugg, Z. 2007. Assessing US Farm Drainage: Can GIS Lead to Better Estimates of Subsurface Drainage Extent? World Resources Institute, Washington, DC. http://www.wri. org/publication/assessing-u-s-farm-drainage-can-gislead-better-estimates-subsurface-drainage-exten.

SWAT. 2013. ArcSWAT: ArcGIS-ArcView extension and graphical user input interface for SWAT. U,S Department of Agriculture, Agricultural Research Service, Grassland, Soil \& Water Research Laboratory, Temple,TX. http://swat.tamu.edu/software/arcswat/.
Tuppad, P., K.R. Douglas-Mankin, T. Lee, R. Srinivasan, and J.G. Arnold. 2011. Soil and Water Assessment Tool (SWAT) hydrologic/water quality model: Extended capability and wider adoption. Transactions of the American Society of Agricultural and Biological Engineers 54(5):1677-1684.

USDA NASS (United Sates Department of Agriculture National Agricultural Statistics Service, 2012. Crop Data Layer (CDL) http://www.nass.usda.gov/research/ Cropland/SARS1a.htm.

USDA NRCS (United Sates Department of Agriculture Natural Resources Conservation Service). 2013. Soil web portal http://soildatamart.nrcs.usda.gov/.

USDA NRCS. 2012. Assessment of the Effects of Conservation Practices on. Cultivated Cropland in the. Upper Mississippi River Basin. The Conservation Effects Assessment Project, Official report, pp 189, weblink: http://www.nrcs.usda.gov/Internet/FSE_ DOCUMENTS/stelprdb1042093.pdf.

USEPA (US Environmental Protection Agency). 2000. Nutrient Criteria Technical Guidance Manual-Lakes and Reservoirs: Office of Water, EPA-822-B-00-001.

USEPA SAB (US Environmental Protection Agency, Science Advisory Board). 2007 Hypoxia in the northern Gulf of Mexico: an update by the EPA Science Advisory Board. EPA-SAB-08-004. Washington, DC: EPA Science Advisory Board, US Environmental Protection Agency.

USGS (US Geological Survey). 2012. Federal Standards and Procedures for the National Watershed Boundary Dataset (WBD). Techniques and Methods 11-A3, Chapter 3 of Section A, Federal Standards Book 11, Collection and Delineation of Spatial Data, Third edition. US Department of the Interior, US Geological Survey, Reston, VA and US Department of Agriculture, Natural Resources Conservation Service, Washington, DC http://pubs.usgs.gov/tm/tm11a3/.

USGS (US Geological Survey). 2013. online water quantity and quality data website: http://waterwatch.usgs.gov/ wqwatch/ and online national elevation data website: http://ned.usgs.gov/.

van Oldenborgh, G.J., S. Philip, and M. Collins. 2005: El Niño in a changing climate: A multi-model study. Ocean Science 1:81-95.

Wang, H., M. Ting, and M. Ji. 1999: Prediction of seasonal mean United States precipitation based on El Niño sea surface temperatures. Geophysical Research Letters 26:1341-1344

Watkins, D., and V. Griffis. 2008. Conditioning ensemble streamflow prediction forecasts using climate signals in the Midwestern US World Environmental and Water Resources Congress 2008. doi: 10.1061/40976(316)519.

Williams, J.R., J.G. Arnold, J.R. Kiniry, P.W. Gassman, and C.H. Green. 2008. History of model development at Temple, Texas. Hydrological Sciences Journal 53(5):948-960, doi: 10.1623/hysj.53.5.948.

Wu, L., S. Liu, and O.I. Abdul-Aziz. 2012. Hydrological effects of the increased $\mathrm{CO} 2$ and climate change in the Upper Mississippi River Basin using a modified SWAT. Climatic Change 110:977-1003, doi: 10.1007/s/10584-011-0087-8. 